\title{
Pallister-Hall Syndrome
}

National Cancer Institute

\section{Source}

National Cancer Institute. Pallister-Hall Syndrome. NCI Thesaurus. Code C84987.

A very rare autosomal dominant inherited disorder caused by mutations in the GLI3 gene.

It is characterized by a spectrum of abnormalities which include polydactyly, cutaneous syndactyly, bifid epiglottis, hypothalamic hamartoma, and laryng otracheal cleft. 